\title{
Christmas nativity scene
}

Teresa Temudo, MD, PhD

Neurology ${ }^{\circledR}$ 2020;95:450-451. doi:10.1212/WNL.0000000000010432
Correspondence

Dr. Temudo

ttemudo11@gmail.com

It didn't make any sense. Strength had progressively started to decrease in the upper limbs. The face was not affected. Pupils were normal, no swallowing change was apparent. It was not botulism. Could it be polyneuropathy? And if so, secondary? There was no history of recent infections. Only the hepatitis B vaccine a month ago. He carried a bag of test results previously performed somewhere else, but nothing relevant, guessing theories missing the target.

The remaining physical examination was normal. An 8-year-old healthy boy called Joaquim, who, a month earlier, had started to lose strength in the upper limbs.

An only child, the youngest son of a couple of street crockery vendors. His sisters were healthy, as well as the rest of the family. Nothing significant from that point of view.

He was right there in front of me. Beautiful as a prince without a kingdom, tall and thin, brownish hair, big honey-colored eyes, and an open and gentle smile. He was a good student and a good son. A perfect child. Bad omen.

My scarce years of experience in neuropediatrics did not make obvious a diagnosis that I would now have made at first sight. I asked for an electromyography and rescheduled the appointment for as soon as I could. But the examination was not timely done, and I had to postpone our meeting. Finally, a month and a half later, the result arrived. Nerve conduction speed was decreased. The most likely hypothesis was a demyelinating polyneuropathy. I called his parents and, 2 days later, Joaquim was admitted to the pediatric department to start an immunoglobulin treatment. The muscular atrophy of the upper limbs was now very conspicuous and the child had no reflexes. The rest of the examination remained normal.

Suddenly that night, he started having difficulty breathing and the next morning it was obvious that the thoracic muscles were affected, and the boy required mechanical ventilation. He was transferred to the ICU and ventilated. Despite everything, he was still in a good mood. Although the tube stuck in his larynx wouldn't allow him to speak, he managed to write on a piece of paper he wanted to watch television.

I got him not only a TV but also a video. My 2 daughters were about his age, so I knew exactly what he liked. I brought him a ream of videotapes, including a movie with Pippi Longstocking.

The next day, Saturday, I went to see him at the hospital in the morning. I was still very young and wouldn't let go of my patients. I found him in a good mood, lying in bed watching TV. His parents, next to him, were reassured to see that his son finally had a diagnosis and was undergoing a specific treatment. Joaquim communicated with me through gestures and managed to ask me to leave the Pippi video for a few more days. Like me, he had loved that rebel fantasy movie. We were approaching Christmas and the parents told me that, at their son's request, they were going to offer me a clay nativity scene. I thank them profusely: if there's one thing I like, it's Christmas and its manger.

The weekend went by. Monday, I went straight to the ICU to see him. When I walked in, I saw a doctor who seemed to be waiting for me. Fearfully, without looking me in the eyes, she told me that a misfortune had taken place the day before. They had extubated Joaquim because they thought he would probably be able to manage without the ventilator. The problem was that his cardiorespiratory and oxygen saturation monitor broke down and the alarm didn't go off when he 
stopped breathing. The boy had gone into prolonged cardiorespiratory arrest and by the time they tried to revive him it was too late. He had irreversible brain damage.

Even today I cannot describe the pain and outrage that assailed me. I felt like screaming and screaming. My boy was there, lying in bed, his eyes dull and fixed, back on ventilation, his parents by his side. They clang to me sobbing, those parents. I could not say a word. My body was tense, my throat was dry, a knife was stuck in my stomach. Tears would come afterwards, as always.

Later that night and for many nights that followed, looking at my daughters about the same age, my voice choked and tears rolled down my cheeks. My daughter Ana said angrily that I should not feel that way about someone who was not my son. I stopped sleeping and sought for professional help for the first time in my life. The psychiatrist who accompanied me ascribed my depression to the death of my brother at the age of 8 , and to an unconscious fear of my daughters' death. I don't know if that was the reason. I worked more than 66 hours a week in the hospital, took care of my family, lived under a great stress. As a recent specialist who worked for 2 years as the only neuropediatrician in a pediatric department, I felt a huge responsibility on my shoulders and I had no one to share my doubts with. The drop had been my outrage over the malfunction of a monitor-cause of the catastrophe. I felt that life was unfair and that my effort was not worth it. The wound caused by my brother's sudden death when I was 11 reopened again and I realized that the grief had never been done. For the first time, with the help of psychotherapy, I was able to talk to someone about this phase of my life that I thought I had overcome. I reviewed childhood photos, talked to my parents without fear of hurting them, openly cried over the loss of such a dear brother. I never stopped working but for 2 months I managed to reduce my schedule. Gradually, after some months, everything went back to normal.

In the meantime, in the absence of a palliative care unit where he could stay, Joaquim was admitted to a smaller hospital. He required permanent and specialized care and his parents had to go back to work. About a year later, one night, I received a call from Joaquim's mother: her son had died in the hospital, from pneumonia. The parents thanked me for everything I had done for him and wanted to give me the clay nativity scene that their son had asked them to offer me. A few days later, there was a box with my name in the consultation room. Inside the box there were several big clay figures made with molds, completely mischaracterized. If the offer hadn't come from Joaquim, that nativity scene would mean nothing to me. I would immediately put it in my garage, as I occasionally did with some of the gifts. But that gift was different. That nativity scene would become the nativity scene of my life, the only one that I would put beside my loving Christmas tree.

The following weekend, equipped with paints and brushes and with the help of my daughters, I decided to paint all the figures. Our Lady's robe in light blue, Saint Joseph's robe in brown, the Magi in purple, crimson, and pink, the cow, the ox, the donkey, each in their own color. The result was awful. The figures were laughable, St. Joseph had a libidinous gaze, and the Magi looked like robbers. What should I do? Christmas was approaching and I was going to use that crib. I recalled there were aging products that might make my nativity scene more discreet. I bought them, read the instructions, and applied a layer over all figures. Even worse. The instructions read that after application a dry cloth should be used and most of the product would be removed, the end result being an "aged look." I cleaned and cleaned again, but the figures looked very dark, with an undefined and sad brown color. I decided to put them in the kitchen sink and with the help of some steel wool I rubbed them vigorously. This time, they looked bare and clayish again. They looked terrible. But this was my nativity scene and I was going to use it. That year, everyone who came to my house asked me why I had such an ugly manger next to such a beautiful Christmas tree.

The following Christmas, I even considered repainting all the figures, this time all beige with golden notes. But a voice inside me told me not to, to leave it as it was, imperfect and with flaws, almost grotesque, to remind me that life is just like that, especially the life of a doctor. With faults, mistakes, omissions, even neglect, and yet standing, not giving up. Proud like an old oak. 


\title{
Neurology
}

\author{
Christmas nativity scene \\ Teresa Temudo \\ Neurology 2020;95;450-451 Published Online before print July 20, 2020 \\ DOI 10.1212/WNL.0000000000010432
}

This information is current as of July 20, 2020

\section{Updated Information \& Services}

\section{Subspecialty Collections}

Permissions \& Licensing

Reprints including high resolution figures, can be found at:

http://n.neurology.org/content/95/10/450.full

This article, along with others on similar topics, appears in the

following collection(s):

All Clinical Neurology

http://n.neurology.org/cgi/collection/all_clinical_neurology

\section{All Pediatric}

http://n.neurology.org/cgi/collection/all_pediatric

Chronic inflammatory demyelinating polyneuropathy

http://n.neurology.org/cgi/collection/chronic_inflammatory_demyelinat ing_polyneuropathy

Error in medicine

http://n.neurology.org/cgi/collection/error_in_medicine

Professional conduct and ethics

http://n.neurology.org/cgi/collection/professional_conduct_and_ethics

Information about reproducing this article in parts (figures,tables) or in its entirety can be found online at:

http://www.neurology.org/about/about_the_journal\#permissions

Information about ordering reprints can be found online:

http://n.neurology.org/subscribers/advertise

Neurology ${ }^{\circledR}$ is the official journal of the American Academy of Neurology. Published continuously since 1951, it is now a weekly with 48 issues per year. Copyright (C 2020 American Academy of Neurology. All rights reserved. Print ISSN: 0028-3878. Online ISSN: 1526-632X.

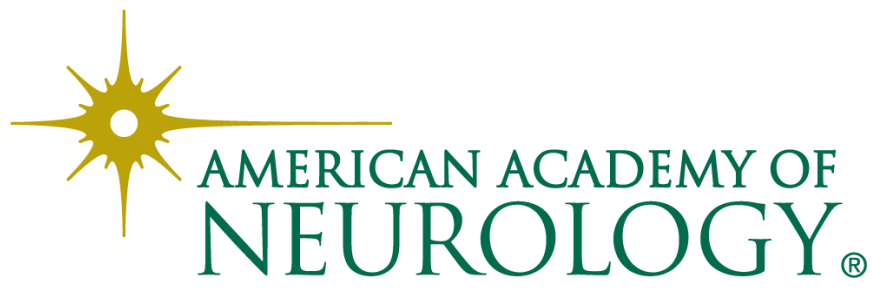

